МОРАЛЬНИЙ ІНТЕЛЕКТ У МОРАЛЬНОМУ РОЗВИТКУ ОСОБИСТОСТІ: ТЕОРЕТИЧНЕ ОБҐРУНТУВАННЯ ФЕНОМЕНУ

\title{
MORAL INTELLIGENCE IN THE MORAL DEVELOPMENT OF PERSONALITY: THEORETICAL SUBSTANTIATION OF THE PHENOMENON
}

у статті презентовано теоретичне обгрунтування морального інтелекту як складника морального розвитку особистості на основі аналітичного огляду наукових праць зарубіжних психологів. здійснено синтез поглядів учених від започаткування поняття «моральний інтелект» (Дж. Босс,1994р.) до найсучасніших тлумачень (наприклад, К. Салех, 2018 р.), у яких виокремлено специфріку та шляхи становлення досліджуваного френомену. Розкрито сутнісний зміст поняття «моральний інтелект» як автономного інтелекту в структурі особистості, що полягає в єдності когнітивного й емоційного складників. На основі наукового доробку таких учених, як М. Бехеuтіфрер, 3. Есмаелі та М. Моѓхадам, М. Борба, Р. Коулс, Д. Нарваез, М. Пач, K. Салех, С. Тео \& Е. Лачлан та інші, предметом дослідження яких було з'ясування особливостей розвитку морального інтелекту в контексті морального розвитку й морального виховання особистості, визначено його структурні компоненти, чинники й методичний інструментарій. Проаналізовано погляди науковців (Р. Коулс, Д. Нарваез) щодо природи морального інтелекту й основи становлення цього психологічного явища на ранніх етапах онтогенезу особистості (ранній, дошкільний і шкільний вік). Доведено, що ффундаментом досліджуваного феномену є конгломерат мислення й чуттєвоcmi, самоповаги й визнання цінності іншого. Здійснено експлікацію когнітивно-емоційної єдності в моральному розвитку особистості, що характеризує фрормування в неі морального інтелекту. Встановлено, що головною детермінантою розвитку морального інтелекту $\epsilon$ моральна свідомість, в основі якої совість - визначник морального поводження особистості. З'ясовано головні чесноти (моральні цінності) (М. Борба) та компетенції/принципи (К. Салех), які сти мулюють розвиток морального інтелекту особистості. Доведено, що врахування специфріки морального інтелекту сприятиме успішному моральному розвитку особистості за умови здійснення дієвої виховної взаємодії. Визначено перспективи подальшого наукового пошуку, що полягатиме в розробленні технології виховного впливу на розвиток морального інтелекту особистості. Ключові слова: моральний інтелект, моральний розвиток, моральне виховання, особистість, моральні емоції та почуття, моральні когніції та судження, моральна поведінка.
The article presents the theoretical justification of moral intelligence as a component of the individual's moral development on the basis of foreign psychologists' analytical review of research. The article highlights synthesis of scientific views from the beginning of the concept of "moral intelligence" interpretation J. Boss (1994) - to the modern, in particular, K. Saleh (2018), which distinguish the specifics and ways of formation of the phenomenon being under study. The essential meaning of the concept of "moral intelligence" as an autonomous intellect in the structure of personality, which consists in the unity of cognitive and emotional components, is revealed. Based on the scientists' study of scientific achievements (M. Beheshtifar, Z. Esmaeli, \& M. Moghadam, M. Borba, R. Coles, D. Narvaez, M. Pats, K. Saleh, C. Teo \& E. Lachlan etc.), the subject of which was to clarify the features of the moral intelligence development in the context of the individual's moral development and moral education, identified its structural components, factors and methodological tools. The views of scientists ( $R$. Coles, D. Narvaez) as to the nature of moral intelligence and the basic foundations of the psychological phenomenon formation in the early stages of personality ontogenesis (from an early age, in preschool and school age) are analyzed. It is proved that the foundation of the studied phenomenon is a conglomeration of thinking and sensuality, self-esteem and recognition of the value of others. The explication of cognitive-emotional unity in the moral development of the individual is carried out, which characterizes the formation of moral intelligence in it. It is established that the main instrumental determinant of the moral intelligence development is moral consciousness, on which conscience as the determinant of individual's moral behavior is based. The basic virtues (moral values) (M. Borba) and competencies/"principles" (K. Saleh) that stimulate the development of the individual's moral intelligence are clarified. It is proved that taking into account the specifics of moral intelligence will contribute to the successful individual's moral development under condition of effective educational interaction. The prospects of further scientific research, which will consist in the development of technology of educational influence on the development of moral intelligence of the growing personality, are determined.

Key words: moral intelligence, moral development, moral education, personality, moral emotions and feelings, moral cognition and judgments, moral behavior.
Постановка проблеми. Питання морального зростання особистості все частіше порушується представниками різних галузей наукової спільноти, що намагаються з'ясувати як психологічні засади, так і оптимальні чинники впливу. У контексті порушеного питання вважаємо за доцільне з'ясувати теоретичні підвалини одного з компонентів морального розвитку - морального інтелекту, започаткування вивчення якого знаходимо в зарубіжній психо- 
логії (М. Борба, Дж. Босс, Р. Коулс, Д. Нарваез, М. Пац та інші) [2; 3-4; 6-7; 9; 12]. Передусім зауважимо, що моральний інтелект - відносно нове та як психологічне явище ще мало досліджене поняття, порівняно з більш усталеними видами (когнітивний інтелект, емоційний, соціальний та інші). Саме тому здійснення аналізу окресленої науково-джерельної бази дасть змогу схарактеризувати сутнісне значення поняття, специфіку становлення зазначеного феномену на різних етапах онтогенезу й особливості врахування його впливу на моральний розвиток особистості.

Аналіз останніх досліджень і публікацій. Інтелект як багатогранне психологічне явище досліджено в теорії «множинного інтелекту» Г. Ґарднера (H. Gardner), який описав його сім видів і назвав цей феномен загальним уніфікованим поняттям, що багато в чому пов'язано з пізнавальною здатністю особистості [8]. Американська вчена Дж. Босс (J. Boss), яку за правом можна вважати провісником у вивченні морального інтелекту, спираючись на проведені Г. Ґарднером дослідження, ввела в науковий обіг новітній термін і розкрила його зміст [3-4]. Позиціонування зазначених наукових ідей Дж. Босс щодо розвитку морального інтелекту знаходимо в працях інших зарубіжних дослідників, таких як М. Бехештіфер, 3. Есмаелі, \& М. Моґхадам, М. Борба, Р. Коулс, Д. Нарваез, К. Салех, С. Тео \& Е. Лачлан та інші [1;2;7-8; 9; 10;11].

Постановка завдання. У своєму дослідженні ми зробили аналітичний огляд наукових праць зарубіжних психологів і можемо стверджувати, що моральний інтелект розглядався як автономний інтелект, сутністю якого $€$ когнітивно-моральна здатність особистості до сприйняття себе та інших з проявом поваги й урахуванням ціннісних орієнтацій оточення. Також нами були виділені структурні компоненти морального інтелекту.

Виклад основного матеріалу дослідження. На думку американської вченої Дж. Босс (J. Boss), інтелект як такий уміщує у своєму складі когнітивний, емоційний і біхевіоральний структурні компоненти, а сутність морального інтелекту - в «єдності мислення та чуттєвості, поваги до себе та інших, визнанні цінностей, наявності розвинених емпатійних здібностей» [4, с. 183-189]. Значущим для наукового осмислення $€$ тлумачення вченою поняття «повага», яке вона розглядала через розвиток судження й таких моральних якостей, як турбота й емпатія та здатність особистості до прийняття моральних рішень. Дж. Босс схарактеризувала складники морального інтелекту: моральні судження, усвідомлення результатів моральної діяльності (когнітивний); прийняття моральних цінностей, вияви емпатії й моральної чутливості (емоційний); здійснення моральних рішень і спрямування власних моральних дій на користь інших (поведінковий) [4, с. 183-189]. Особливий акцент дослідниця ставила на розвиткові моральної інтуїції, совісті, які посутньо складають серцевину в системі структурних компонентів морального інтелекту. Дж. Босс також зауважила, що в цій системі безумовним стрижнем діяльності особистості має бути чітке дотримання моральних правил і норм і виконання всіх моральних імперативів. За її вченням, спектр повинності фактично відповідає моральному інтелекту [3].

Позиціонування зазначених наукових ідей Дж. Босс щодо розвитку морального інтелекту знаходимо в працях інших зарубіжних дослідників, таких як М. Бехештіфер, 3. Есмаелі, \& М. Моґхадам, М. Борба, Р. Коулс, Д. Нарваез, К. Салех, С. Тео \& Е. Лачлан та інші $[1 ; 2$; $7-8 ; 9 ; 10 ; 11]$. Зокрема, значний науковий інтерес становлять погляди професора Гарвардського університету P. Коулса (R. Coles), автора праці «Моральний інтелект дітей: як виховати моральну дитину» [7]. В основу створеної вченим концепції розвитку морального інтелекту покладено ідею врахування моральних цінностей, усвідомлення яких ґрунтується на осмисленні моральних принципів (когнітивний складник), їх емоційному прийнятті у внутрішній план дій (емоційний складник) і безапеляційному дотриманні впродовж усього життя (поведінковий складник). Р. Коулс наголошував, що завдання дорослих полягає в тому, щоб скористатися «моральними моментами», а саме тими моральними ситуаціями й подіями, які дитиною переживаються найбільше, коли усвідомлення моральних принципів посилюється, що веде до моделювання позитивної поведінки дітей [6]. Науковець стверджував, що дитина постійно перебуває в просторі, який може бути належно моральним або навпаки, і стає свідком виконання встановлених моральних норм дорослими чи порушення ними [6]. Р. Коулс підкреслив, що в умовах, коли дітям часто доводиться спостерігати демонстрацію морально неналежної поведінки дорослими, це порушує формування в них моральних цінностей, вносить дисбаланс, а отже, негативно відбивається на розвиткові морального інтелекту [6-7].

Р. Коулс, як і Дж. Босс [3-4], доводив, що моральний інтелект є автономним видом інтелекту, сутнісне значення якого - забезпечення особистості можливості ставати «морально розумною", що безпосередньо впливає на становлення ії внутрішнього світу, розвиває в неї співпереживання, повагу до себе та інших [6-7]. Постулюючи золоте правило моралі, авторство якого приписують Арістотелю, Р. Коулс розробив цілісну систему розвитку морального інтелекту, в основі 
якої - спостереження за поведінкою з подальшим обговоренням, вправляння у вияві турботи про інших і моральні бесіди [6-7]. Вчений наголошував, що в моральному розвитку важливим $€$ врахування «конгруентності у словах і діях», тобто, щоб моральні судження проєктувалися в моральній поведінці, а не розходилися [6-7]. 3 означеного вирізняється розроблення дослідником методичного інструментарію стосовно досліджуваного феномену.

Значний науковий інтерес становлять наукові положення Р. Коулса в контексті розгляду ним так званої «моральної археології дитинства», сутність якої - визначення специфіки морального розвитку особистості на різних етапах онтогенезу [7]. Зокрема, він вважав, що на немовлячий період припадає початок «морального життя», коли дитина ще не виявляє чітких ознак моральної вихованості чи моральної невихованості; впродовж передшкільного віку відбувається становлення совісті, а ключовий розвиток припадає на шкільний вік [7]. Від усіх проаналізованих наукових праць дослідження Р. Коулса відрізняється прогресивністю поглядів стосовно розробленої ним «моральної археології дитинства» i, що особливо важливо, визначення головної детермінанти - розвитку почуття совісті й моральної свідомості дитини, що формуються, як стверджував учений, на ранніх етапах життя на основі моральних переконань, здатності до прийняття моральних рішень і взірців поведінки значущих дорослих [7].

Дослідники С. Тео та Е. Лачлан (C. Тео \& E. Lachlan) висловили суголосність з науковими позиціями Р. Коулса, зауваживши про важливість урахування розвитку морального інтелекту, який слугує «керунком специфічної системи поведінки», сутність якої полягає в тому, що діти приходять до пізнання добра й права, починають роздумувати над моральними питаннями й усвідомлюють значення моральних норм [11]. На думку С. Тео та Е. Лачлан, виховання морального інтелекту у формальному розумінні - це забезпечення цілеспрямованої активної позиції дитини як суб'єкта виховного процесу з метою морального зростання та розвитку морального судження. Дослідники вважали, що на розвиток морального інтелекту дітей мають вплив три основні чинники: найближче оточення, моделювання моральних ситуацій і специфічний виховний процес [11]. Oсобливу увагу в розвитку морального інтелекту С. Тео й Е. Лачлан приділяли здатності особистості робити морально-етичний вибір, що обумовлювало її піднесення на вищий щабель морального зростання.

Прогресивними ідеями, на нашу думку, вирізняється науковий доробок М. Борби (M. Borba), яка зауважила, що моральний інтелект доцільно розуміти як «маятник», який допомагає відрізнити правильне від неправильного [2]. Заслуговують на увагу розроблені М. Борбою рекомендації, у який спосіб розвивати моральний інтелект у дітей віком від 3 до 15 років [2]. Учена зазначила на фактах епідемічного дефіциту морального розвитку американських дітей сім чеснот, які вміщує моральний інтелект: емпатія (empathy), совість (conscience), самоконтроль (selfcontrol), повага (respect), доброта (kindness), толерантність (tolerance), справедливість (fairness), розвиток яких має підвищити рівень морального зростання особистості [2]. М. Борба, як і Р. Коулс, головною детермінантою означила позитивний моральний приклад батьків і створення оптимальних умов для формування моральних переконань і доброчесної поведінки дітей. М. Борба розробила покрокову програму розвитку морального інтелекту, основу якої складала чітка концептуалізація навчання чеснот, формування морального характеру й моральних цінностей [2]. Отже, за вченням М. Борби саме зазначені сім найважливіших чеснот складають моральний інтелект, а культивування й опанування їхнього значення визначає спрямування морального розвитку дітей.

Подальше вивчення зазначеного феномену знаходимо в дослідженнях А. Браун-Міллер (A. Browne-Miller), яка назвала моральний інтелект ключовим у моральному розвитку особистості [5]. Вчена зауважила, що його сутнісне значення полягає в підвищенні потенціалу особистісного зростання загалом. Психологинею надано поради, як забезпечити розвиток морального інтелекту в дітей і підлітків [5]. Зокрема, А. Браун-Міллер окреслила такі основні засоби розвитку: використання фольклору, комфортне перебування в різних соціальних осередках, проведення тематичної освітньої роботи. Зазначені положення дають підстави зробити висновок, що вчена акцентувала увагу на ролі морального виховання в моральному розвитку особистості з опорою на її моральний інтелект.

Посутнє значення досліджуваного явища розкрито в низці робіт однієї з фундаторок моральної психології - американської вченої Д. Нарваез (D. Narvaez) [9]. Ï̈̈ концепція розвитку морального інтелекту ґрунтується на емоціях і розумі, чим повторює ідеї про емоційно-когнітивну єдність, які окреслила Дж. Босс [3-4]. Однак Д. Нарваез значно глибше й докладніше обґрунтувала природу морального інтелекту, спираючись на розроблену нею теорію триєдиної етики (ТЕT - theory of triune ethics), в основі якої лежить системне тлумачення нейронаукових, еволюційних й експериментальних висновків, що пояснюють відмінності морального функціонування 
особистості [9]. Вчена підкреслила, що теорія триєдиної етики поєднує в собі забезпечення етики безпеки, залучення дітей до моральної взаємодії та розвиток моральної свідомості, становлення яких може відбуватися диспозиційно на підставі заохочення позитивного морального досвіду в чутливі (сенситивні) періоди, а також у спеціально створених умовах, що потребують розв'язання моральної ситуації [9]. Д. Нарваез стверджувала, що нейронаукові та клінічні дослідження яскраво ілюструють, у який спосіб співрегуляція та взаємодія з дорослими впливають на емоційність, моральне пізнання й моральну поведінку на ранніх етапах онтогенезу. Зріле моральне функціонування особистості має пряму залежність від інтеграції емоцій, інтуїції та моральних міркувань, які об'єднуються у феномен, що називається моральний інтелект [9]. Для його розвитку вчена радила застосовувати інтегративну модель етичної освіти в закладах різних освітніх рівнів.

Науковці М. Бехештіфер, 3. Есмаелі та М. Моґхадам (М. Beheshtifar, Z. Esmaeli \& M. Moghadam) визначили моральний інтелект «компасом» життєдіяльності особистості, сутність якого полягає в здатності розмежовувати належне й неналежне, в умінні людини «жити за загальними моральними принципами», що вирізняє її моральну поведінку [1]. Вчені зауважили, що моральний інтелект не лише визначає вектор поводження відповідно до встановлених чітких моральних правил, яких потрібно дотримуватися в суспільстві, але й спрямовує до здійснення моральних вчинків [1]. Особистість 3 розвиненим моральним інтелектом вирізняється чутливим, турботливим, «співучасним» ставленням до інших у реальних життєвих ситуаціях, швидким вирішенням проблем і прийняттям стратегічних рішень.

Дещо інші наукові положення стосовно визначення сутності морального інтелекту запропоновано в дослідженні М. Пац [12]. За результатами проведеного аналізу можемо стверджувати, що в алгоритмічному процесі розвитку морального інтелекту особистості М. Пац окреслив домінування зародження совісті, яке має когнітивне й афективне підґрунтя. При цьому когнітивний чинник вказує на те, що є добро, а що - зло, яких універсальних моральних принципів потрібно дотримуватися. Відповідно афективний виконує спонукальну роль, що полягає у виявленні моральних почуттів й емоцій (симпатії, співчуття, співпереживання, провини, сорому тощо) [12]. Зазначене дає підстави зробити узагальнення, що, згідно з науковими ідеями М. Пац, моральний інтелект у моральному розвитку особистості зумовлює моральну мотивацію, поштовх якої забезпечують сформовані прояви сові- сті, моральної інтуїції, емпатії та здатність до моральної рефлексії. Нам також імпонує наукова позиція, висловлена дослідником про те, що моральний інтелект доречно розглядати як єдність мислення й емоційного сприйняття навколишнього світу, що виражається в повазі особистості до самої себе й у визнанні цінності інших і створює можливості для ефективного морального виховання [12].

Наукову цінність становлять результати одного з найновіших досліджень, що проведено K. Салех (K. Saleh), завдяки чому розкрито сутнісний зміст морального інтелекту як психологічного явища й доведено, що його можна вважати самостійною формою інтелекту [10]. Заслуга науковця полягає в тому, що він розробив концепцію розвитку в дітей морального інтелекту в межах виховання «морального характеру». К. Салех підкреслив, що моральний інтелект передусім «керується» моральним розумінням і спрямований на вдосконалення моральної поведінки й презентацію власної позиції стосовно з'ясування змісту моральних ситуацій [10]. Дослідник підтверджує положення Дж. Босс [3-4], що в розвитку морального інтелекту обов'язковим $€$ врахування єдності когнітивного й емоційного складників, оскільки саме це забезпечує формування поваги до цінностей інших. К. Салех наголосив на важливості застосування етично орієнтованого підходу в організації виховної взаємодії з дітьми [10].

У розробленій К. Салехом концепції на увагу заслуговує й компетентнісний підхід у розвитку морального інтелекту особистості [10]. Зокрема, учений визначив потребу у формуванні таких його складників, як-от: цілісність (integrity), відповідальність (responsibility), співчуття (compassion) і прощення (forgiveness). Він назвав їх компетенціями/ принципами морального інтелекту, окресливши сутність кожного з них. За нашим аналізом, запропонована К. Салех система компетенцій/принципів у своїй основі об'єднала окреслені М. Борбою [2] сім моральних чеснот (моральних цінностей). Це дало науковцю підстави визначити моральний інтелект складним психологічним явищем як за структурою, так і за змістом [10]. Водночас він зауважив, що в освітній процес роботи з дітьми доцільно інтегрувати завдання розвитку в них морального інтелекту, що забезпечить їхнє моральне зростання і особистісне становлення. Дослідник наводив переконливі аргументи, що сучасне суспільство потребує нових громадян з високо розвиненим моральним інтелектом, здатних до розв'язування моральних дилем.

На основі теоретичного аналізу обґрунтування морального інтелекту в моральному розвитку особистості робимо узагальнення, 
що всі без винятку науковці (М. Бехештіфер, 3. Есмаелі, \& М. Моґхадам, Дж. Босс, Р. Коулс, Д. Нарваез, М. Пац та інші) висловилися одностайно щодо потреби врахування структурних компонентів досліджуваного феномену та його особливостей $[1 ; 3-4 ; 6-7 ; 9 ; 12]$. Найоптимальніше розвиток здійснюється в моральному вихованні, в процесі якого формуються когнітивні, емоційні константи й відбувається становлення моральної поведінки особистості. У низці наукових робіт (М. Борба, А. Браун-Міллер, Р. Коулс, К. Салех, С. Тео \& Е. Лачлан та інших) презентовано основний методичний інструментарій для розвитку морального інтелекту особистості [2; 5; 6-7; 10; 11]. Підсумовуємо: моральний інтелект має великий потенціал для поліпшення морального пізнання навколишньої дійсності та становлення доброчесної поведінки.

Висновки 3 проведеного дослідження. Отже, на основі проведеного аналітичного огляду наукових праць зарубіжних психологів можемо стверджувати, що моральний інтелект розглядався як автономний інтелект, сутністю якого $€$ когнітивно-моральна здатність особистості до сприйняття себе та інших з проявом поваги та врахуванням ціннісних орієнтацій оточення. Структурними компонентами морального інтелекту окреслено моральні когніції/судження, моральні емоції/ почуття та моральну поведінку, що об'єднані в єдину систему та є основою морального розвитку особистості. Вивчення морального інтелекту має посісти чільне місце в дослідженнях морального розвитку особистості на різних етапах онтогенезу.

Перспективами подальшої наукової роботи вбачаємо з'ясування розвитку морального інтелекту особистості в системі виховної взаємодії.

\section{ЛITEPATУРA:}

1. Beheshtifar M., Esmaeli Z., Moghadam M.N. Effect of Moral Intelligence on Leadership. European Journal of Economics, Finance and Administrative Sciences. 2011. Is. 43. P. 6-11.

2. Borba M. Building Moral Intelligence: The Seven Essential Virtues that Teach Kids to Do the Right Thing. New York : Jossey-Bass, 2010. 337 p.

3. Boss J.A. The autonomy of moral intelligence. Education Theory. 1994. Is. 44. Vol. 4. P. 399-416. URL: https://doi.org/10.1111/j.1741-5446.1994.00399.x.

4. Boss J.A. The effect of community service work on the moral development of college ethics students. Journal of Moral Education. 1994. Is. 23, Vol. 2. P. 183-198.

5. Browne-Miller A. Raising Thinking Children and Teens: Guiding Mental and Moral Development. California : ABC-CLIO Incorporated, 2009. 204 p.

6. Coles R. The moral intelligence of children. Family Court Review. 1998. Is. 36, Vol. 1. P. 90-95.

7. Coles R. The Moral Intelligence of Children: How to Raise a Moral Child. New York : Publishing Plume, 1998. 218 p.

8. Gardner $\mathrm{H}$. The tensions between education and development. Journal of Moral Education. 1991. Is. 20, Vol. 2. P. 113-125.

9. Narvaez D. The emotional foundations of high moral intelligence. Children's Moral Emotions and Moral Cognition: Developmental and Educational Perspectives, New Directions for Child and Adolescent Development. B. Latzko \& T. Malti (Eds.) San Francisco : Jossey-Bass, 2010. Vol. 129. P. 77-94. URL: https://doi.org/10.1002/cd.276.

10. Saleh K. Moral Intelligence and its Role in Formulating Children Characters. Multi-Knowledge Electronic Comprehensive Journal For Education And Science Publications (MECSJ). 2018. Is. 7. P. 301-313.

11. Teo C.T., Lachlan E.D. Developing the moral intelligence of children. Crawford Source REACT. 2000. Is. 2. P. 41-46.

12. Пац М.В. Нравственный интеллект как ценность современного образования. Казанский педагогический журнал. 2011, № 1. С. 26-31. 